\title{
Integrated Farming System: Profitable Farming to Small Farmers
}

\author{
Kamble Anand Shankar ${ }^{*}$, L.N. Yogeesh, S.M. Prashant, P. Sheik Peer and B.K. Desai \\ Agricultural Research Station, Hagari 583111, Ballari, University of Agricultural Sciences, \\ Raichur, Karnataka, India \\ *Corresponding author
}

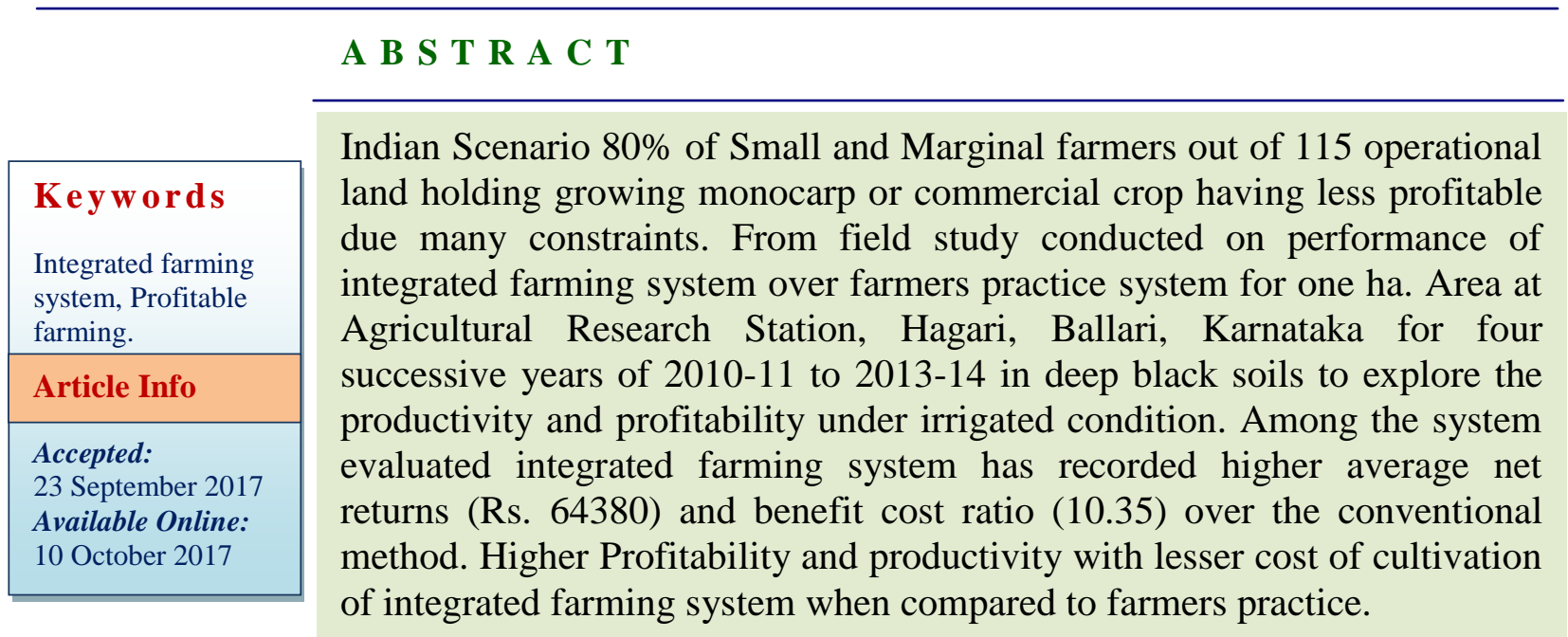

\section{Introduction}

In the present scenario the demand and supply for food has changed due to higher population and the shift of people in the cropping pattern. The per capita availability of land is decreasing day to day because of increasing in the population. So in order to meet out the demand of increasing population to produce more quantity by maintaining the quality of food in limited area. By adopting the integrated farming system which requires lesser space and ensures higher productivity of the system is the only option which left out for us. The practice of cash return farmers will improve the economic condition of the farmers. The integrated farming system includes dairy, poultry, goat rearing and fruit trees with dominant cropping systems in order to judicious use of inputs and natural resources to provide the regular income and employment to small and marginal farmers.

In Karnataka, majority of the farmers holds less than 2 ha of land. These farmers generally practice conventional farming, where they need to produce continuous reliable and balanced supply of food as well as cash for basic needs and recurrent farm expenditure. So these need to develop suitable integrated farming system for farmers to avoid the crop loss and to generate employment and income generation throughout year. Integrated farming system 
lead the way to increase the production of the small farmers. Multi enterprise farming has the chance to decrease the production cost by synergetic recycling of product of various components to provide the income and employment. Keeping the view, an experiment was conducted at Agricultural research station farm, Hagari to study the comparison between the farmers practicing system and integrated farming system under irrigated condition.

\section{Materials and Methods}

Experiment was conducted at Agricultural research station farm, Hagari to study profitability and productivity of Integrated Farming System for four successive years of 2010-11 to 2013-14. The Agricultural research station farm, Hagari is situated in Northern Dry Zone (Zone 3) of Karnataka state with an altitude of 1000 meters above the mean sea level. The soil was deep black with a $\mathrm{pH}$ of 8.32. The available Nitrogen, phosphorous and potassium were 60.2, 25.4, $141.5 \mathrm{~kg} \mathrm{ha}^{-1}$, respectively.

The experiment consist of growing of field crops for one ha (conventional method) and integrated farming system (IFS). The IFS model consisting of one ha.land holding with the components viz., Crop and Cropping sequence $\left(9000 \mathrm{~m}^{2}\right)$, Livestock $\left(300 \mathrm{~m}^{2}\right)$, Farm pond $\left(300 \mathrm{~m}^{2}\right)$, Composting unit, storage $\left(250 \mathrm{~m}^{2}\right)$ and Farmhouse $\left(150 \mathrm{~m}^{2}\right)$.

IFS Model for irrigated ecosystem (1 ha Area), Hagari

All along the border-planting of Jamun, Sapota on the bunds and creeping vegetables on the fence were planted. Between the segments are planted with improved varieties of Drumstick, Curry leaf and fodder crops. On the border of land we have planted the fodder crops.
Composting unit, storage godown, threshing floor etc: $150 \mathrm{~m}^{2}$ area

To sustain the productivity the residues obtained in the system was recycled. The productivity of the farmers practice method and integrated farming system was based on the quantity of marketable produce obtained during all four years. A multi-disciplinary research team representing the disciplines of agronomy, soil science, animal science, farm power machinery engineering and agricultural economics was involved for in-depth analysis of data.

\section{Results and Discussion}

Results of four years of conventional method and integrated farming systems are discussed here. The productivity of the farming systems was based on the quantity of marketable produce obtained during all four years. Integrated farming system method (IFS) recorded higher productivity and profitability than farmers practice method. The farmers practice method recorded net returns of Rs. 55000 with $2.85 \mathrm{~B}$ : C ratio (Table 1). IFS method records higher net returns and benefit cost ratio in all the four years because this method comprises the components like cropping, vermicompost, goat rearing and cattle (bullocks, cow and calves) rearing. At the end of third year IFS method contributed a net return of Rs. 72835 (average of 4 years) with benefit cost ratio of 2.87 which gives 24.53 per cent higher net returns compared tofarmers practicemethod. Similar results were reported by Ugwumba et al., (2010) and Ortega et al., (2009 a). Higher net income generated during third year compared to first and second year due to increase in the milk yield by the livestock and proper recycling of farm resources each other through use of vermicompost contributed to good returns. These results are in accordance with Channabasavanna et al., (2009) was stated 
IFS approach recorded 26.3 and 32.3 per cent higher productivity and profitability respectively over conventional system in rice ecosystem. The results indicated IFS become more profitable during perennial years compared to single year.

Among components studied in irrigated IFS method, field crops + diary + vermicomposting unit was more profitable than growing of single crop. This system has recorded average net returns of Rs. 72835 with $2.87 \mathrm{~B}$ : C ratio (Table 1). Similar results reported by Jayanthi et al., (2003), Channabasavanna et al., (2009), Ugwumba et al., (2010), Singh et al., (2009) and Ravishankar et al., (2007).

Among enterprises studied animal components recorded higher net income than crop and cropping sequences. These results are in accordance with Jahan et al., (2011) and Sachinkumar et al., (2012) reported inclusion of allied activity for small farms to increase income and promote ecological soundness. Similar results reported by Dey et al., (2010) and Torane et al., (2009).

\section{Organic manures from livestock components of IFS method}

The available quantity of organic manures obtained from the livestock components of IFS are presented in Table 2. Available organic manure on wet weight basis was $24.22,27.77,27.95$ and $29.32 \mathrm{t}$ and on dry weight basis available manure was 16.61 , $14.84,15.36$ and $16.11 \mathrm{t}$ from livestock unit. The nutrient content on dry weight basis of manure is presented in Table 3. In the integrated farming system farmers have practiced the poultry unit during 2012-13 and 2013-14. By the first year the income was less because of initial higher cost of cultivation for the establishment of the unit. During the second year higher net returns was recorded because there was no establishment cost for the poultry unit.

Table.2 Quantity of organic manures produced from livestock components

\begin{tabular}{|c|c|c|c|}
\hline $\begin{array}{c}\text { S. } \\
\text { No }\end{array}$ & Year & $\begin{array}{c}\text { Wet weight } \\
\text { (t/year) }\end{array}$ & $\begin{array}{c}\text { Dry weight } \\
\text { (t/year) }\end{array}$ \\
\hline 1 & $2010-11$ & 24.22 & 16.61 \\
\hline 2 & $2011-12$ & 27.77 & 14.84 \\
\hline 3 & $2012-13$ & 27.95 & 15.36 \\
\hline 4 & $2013-14$ & 29.32 & 16.11 \\
\hline
\end{tabular}

Table.3 The nutrient content on dry weight basis of manure

\begin{tabular}{|c|c|c|c|c|}
\hline $\begin{array}{c}\text { S. } \\
\text { no }\end{array}$ & Particulars & $\begin{array}{c}\text { Nitrogen } \\
(\mathbf{\%})\end{array}$ & $\begin{array}{c}\text { Phosphorous } \\
(\mathbf{\%})\end{array}$ & $\begin{array}{c}\text { Potassium } \\
(\mathbf{\%})\end{array}$ \\
\hline 1 & Cattle manure & 0.71 & 0.44 & 0.91 \\
\hline 2 & Cattle urine & 1.31 & 0.08 & 0.70 \\
\hline 3 & Goat manure & 1.53 & 1.40 & 0.18 \\
\hline 4 & Goat urine & 1.64 & 0.03 & 0.35 \\
\hline
\end{tabular}




\section{Int.J.Curr.Microbiol.App.Sci (2017) 6(10): 2819-2824}

Table.1 Yield and economics of different cropping sequences under integrated farming systems in irrigated condition

\begin{tabular}{|c|c|c|c|c|c|c|c|c|c|c|c|c|c|c|c|c|c|c|c|c|c|}
\hline Year & \multicolumn{6}{|c|}{ 2010-11 } & \multicolumn{5}{|c|}{ 2011-12 } & \multicolumn{5}{|c|}{ 2012-13 } & \multicolumn{5}{|c|}{ 2013-14 } \\
\hline $\begin{array}{l}\text { Cropping } \\
\text { sequence }\end{array}$ & Area & $\begin{array}{c}\text { Yiel } \\
\text { d } \\
(\mathbf{q t})\end{array}$ & $\begin{array}{c}\text { Cost of } \\
\text { Cultivation }\end{array}$ & $\begin{array}{c}\text { Gross } \\
\text { returns }\end{array}$ & $\begin{array}{c}\text { Net } \\
\text { returns } \\
\text { (Rs.) }\end{array}$ & $\begin{array}{l}\text { B:C } \\
\text { ratio }\end{array}$ & $\begin{array}{l}\text { Yield } \\
\text { (qt) }\end{array}$ & $\begin{array}{c}\text { Cost of } \\
\text { Cultivation }\end{array}$ & $\begin{array}{c}\text { Gross } \\
\text { returns }\end{array}$ & $\begin{array}{c}\text { Net } \\
\text { returns } \\
\text { (Rs.) }\end{array}$ & $\begin{array}{l}\text { B:C } \\
\text { ratio }\end{array}$ & $\begin{array}{c}\text { Yield } \\
(\mathbf{q t})\end{array}$ & $\begin{array}{c}\text { Cost of } \\
\text { Cultivati } \\
\quad \text { on }\end{array}$ & $\begin{array}{c}\text { Gross } \\
\text { return } \\
\mathrm{s}\end{array}$ & $\begin{array}{c}\text { Net } \\
\text { retur } \\
\text { ns } \\
\text { (Rs.) }\end{array}$ & $\begin{array}{l}\text { B:C } \\
\text { ratio }\end{array}$ & $\begin{array}{c}\text { Yield } \\
(\mathbf{q t})\end{array}$ & $\begin{array}{c}\text { Cost of } \\
\text { Cultivat } \\
\quad \text { ion }\end{array}$ & $\begin{array}{c}\text { Gross } \\
\text { returns }\end{array}$ & $\begin{array}{c}\text { Net } \\
\text { returns } \\
\text { (Rs.) }\end{array}$ & $\begin{array}{l}\text { B:C } \\
\text { ratio }\end{array}$ \\
\hline Vegetable & 0.08 & $15 \mathrm{~kg}$ & 180 & 600 & 420 & 2.3 & $22 \mathrm{~kg}$ & 220 & 1000 & 780 & 3.54 & $26 \mathrm{~kg}$ & 436 & 1300 & 864 & 1.98 & .00 & 425 & 1650 & 1225 & 2.88 \\
\hline $\begin{array}{l}\text { Fruit Crops+ } \\
\text { Maize/ } \\
\text { Bengal gram }\end{array}$ & $\begin{array}{l}0.20 / \\
0.40\end{array}$ & -- & -- & -- & -- & -- & -- & -- & -- & -- & -- & $9.5 \mathrm{q}$ & 1465 & 13350 & 11885 & 8.1 & 4.50 & 1900 & 13500 & 11600 & 6.10 \\
\hline $\begin{array}{l}\text { Sorghum- } \\
\text { Chickpea }\end{array}$ & 0.20 & $5 \mathrm{q}$ & 1200 & 12500 & 11300 & 9.4 & $4 q$ & 1300 & 8000 & 6700 & 5.15 & $4.8 \mathrm{q}$ & 470 & 10600 & 10030 & 17.59 & -- & -- & -- & -- & -- \\
\hline $\begin{array}{l}\text { Cotton- } \\
\text { Greengram/ } \\
\text { Sorghum }\end{array}$ & 0.40 & -- & -- & -- & -- & -- & $25 \mathrm{~kg}$ & 420 & 1100 & 680 & 1.61 & $6 \mathrm{q}$ & 5792 & 21000 & 15208 & 2.62 & 7.25 & 1550 & 14500 & 12950 & 8.35 \\
\hline Total & 0.90 & 5.15 & 1380 & 13100 & 11720 & 8.4 & 4.47 & 1940 & 10100 & 2130 & 8160 & $20.56 q$ & 8163 & 46250 & 37987 & 4.65 & 11.86 & 3875 & 29650 & 25775 & 5.78 \\
\hline \multicolumn{22}{|c|}{ Allied activities } \\
\hline Dairy & $\begin{array}{c}2 \\
\text { cows } \\
3 \text { calf }\end{array}$ & $\begin{array}{l}1577 \\
.7 \mathrm{ltr}\end{array}$ & 10000 & 34695 & 24695 & 2.46 & $1439 \mathrm{ltr}$ & 10000 & 31658 & 21658 & 2.16 & 3391.78 & 18720 & 74619 & 55899 & 2.98 & $\begin{array}{c}36001 \mathrm{lt} \\
\mathrm{r}\end{array}$ & 22500 & 79200 & 56700 & 2.52 \\
\hline Poltry & $\begin{array}{l}32 / 42 \\
\text { birds }\end{array}$ & -- & -- & -- & -- & -- & -- & -- & -- & -- & -- & $98 \mathrm{~kg}$ & 6937 & 11760 & 4827 & 0.69 & 1.10 & 4150 & 11000 & 6850 & 1.65 \\
\hline $\begin{array}{l}\text { Vermicompo } \\
\text { st unit }\end{array}$ & $\begin{array}{c}3 \\
\text { units }\end{array}$ & $30 q$ & 500 & 6000 & 5500 & 11.0 & $30 \mathrm{q}$ & 600 & 6000 & 5400 & 9.0 & $90 \mathrm{q}$ & -- & 9000 & 9000 & -- & 60.0 & 1800 & 24000 & 22200 & 12.30 \\
\hline Azolla & $3 \times 2 \mathrm{~m}^{2}$ & $\begin{array}{c}42.7 \\
5\end{array}$ & 1950 & -- & -- & -- & $42 q$ & 1680 & -- & -- & -- & -- & 1475 & -- & -- & -- & 0.80 & -- & -- & -- & -- \\
\hline $\begin{array}{l}\text { Green } \\
\text { fodder on } \\
\text { bunds }\end{array}$ & $\begin{array}{c}0.03 \\
\text { ha }\end{array}$ & $80 \mathrm{~kg}$ & 200 & -- & -- & -- & $76 \mathrm{~kg}$ & 200 & -- & -- & -- & $87 \mathrm{~kg}$ & 200 & -- & -- & -- & 0.86 & 200 & -- & -- & -- \\
\hline Total & & -- & 12650 & 40695 & 30195 & 2.38 & -- & 12480 & 37658 & 27058 & 2.16 & -- & 27332 & 95373 & 69726 & 2.55 & -- & 28650 & 114200 & 85750 & 5.49 \\
\hline $1^{\text {st }}$ year & 1 ha & -- & 14030 & $\mathbf{5 3 7 9 5}$ & 41915 & 2.98 & $\begin{array}{c}2^{\text {nd }} \\
\text { year }\end{array}$ & 14420 & 47758 & 29188 & 2.02 & $3^{\text {rd }}$ year & 35495 & 141623 & $\begin{array}{c}10771 \\
3\end{array}$ & 3.03 & $\begin{array}{c}4^{\text {th }} \\
\text { year }\end{array}$ & 32525 & 143850 & 112525 & 3.46 \\
\hline
\end{tabular}




\section{Horticulture in IFS method}

The raised dykes of the pond lead to generate additional income to the farming community. Income generated during particular year may vary because of seasonal market demand, availability of inputs, labour availability etc.

\section{Vermicompost production in IFS method}

During lean period activities viz., compost preparation and vermicompost production activities taken up in the IFS module to recycle the animal wastes, crop residues, grass and fodder tree wastes etc within the farm. In all four years on an average about 48.5 quintals vermicompost produced and used as farm input and also sold as the manures to farmers. The integrated farming system provides excellent opportunity for organic recycling, moreover, and it reduces farmer's dependency on external or market purchased inputs. It offers good scope for recycling of crop components to the animals and vice versa.

\section{Survival of farm family}

As per trial one farm family consisted farmer, his wife and two children were leaves in farm house. Both farmer and his wife use to work in IFS method. During all cropping Season farm family meeting their food requirements from farm produce. Farm family members satisfied they are getting diversified produces in their own farm and it includes nutritional vegetables, cereals, pulses, oilseeds, milk, fruits and others. So the family secure in terms of nutrition and food through integrated farming system method.

It is clear from the above results that IFS method for irrigated situations enhances productivity, profitability and nutritional security of the farmer and sustains soil productivity through recycling of organic sources of nutrients from the enterprises involved. In this system, animals are reared on agricultural waste and animal power is used for agricultural operation and voids are used as manure and fuel. The most notable advantage of utilizing low-cost/no-cost material at the farm level for recycling is that it will certainly reduce the production cost and ultimately improve the farm income considerably.

\section{References}

Channabasavanna, A.S., Biradar, D.P., Prabhudev, K.N. and Mahabhaleswar Hegde 2009. Development of profitable integrated farming system model for small and medium farmers of Tungabhadra project area of Karnataka. Karnataka Journal of Agriculture Science 22 (1): 25-27.

Dey, M.M., Paraguas, F.J., Kambewa, P. and Pemsl, D.E 2010. The impact of integrated aquaculture-agriculture on small-scale farms in Southern Malawi.Agricultural Economics 41: 6769.

Jahan, K.M., and Pemsl D.E., 2011. The impact of integrated aquacultureagriculture on small-scale farm sustainability and farmers' livelihoods: Experience from Bangladesh. Agricultural Systems 104: 392- 402.

Jayanthi, C., Baluswamy, M., Chinnusamy, C. and Mythily, S., 2003. Integrated nutrient supply system of linked components in lowland integrated farming system. Indian Journal of Argonomy48: 241-246.

Main, M. R.U., Mazher, K. and Islam, M. S 1988. An economic analysis homestead farming in some selected areas of Mymensingh district. Bangladesh Journal of Training and Development 11 (1\&2): 123-130.

Ortega, and Maximiliano 2009a. Integrated 
Farming System - A training report. Presented at Workshop on Integrated Farming System held on 27 February 2009 at Central Farm, Cayo District, Belize.

Ravishankar, N., Pramanik, Rai, S. C., Shakila Nawab., Topan. R, B., Biwas, K. R. and Nabisat Bibi 2007. Study on integrated farming system in hilly areas of Bay Islands. Indian Journal of Agronomy 52: 7-10.

Sachinkumar, T.N., Basavaraja, H., Kunnal, L.B. Kulkarni, G.N., Ahajanashetty, S.B., Hunshal, C. S. and Hosamani, S. V 2012. Economics of farming systems in northern transitional zone of Karnataka. Karnataka Journal of Agriculture Science 25 (3): 350-358.

Shanmugasundaram, V. S., Balusamy, M. and Rangasamy, A 1995. Integrated farming system research in Tamilnadu. Journal of Farming Systems Research and Development 1 (1): 1-9.

Singh, S.P., Gangwar, B. and Singh, M.P 2009. Economics of Farming Systems in Uttar Pradesh Agricultural Economics. Research Review 22: 129138.

Torane, S.R., 2009. An econometric analysis of farming systems in north Konkan region of Maharashtra. Ph.D. Thesis, Univ. Agric. Sci., Dharwad (India).

Ugwumba, C.O.A., Okoh, R.N., Ike, P.C., Nnabuife, E.L.C. and Orji E.C 2010. Integrated Farming System and its Effect on Farm Cash Income in Awka South Agricultural Zone of Anambra State, Nigeria. American-Eurasian Journal of Agriculture \& Environmental Science 8 (1) : 01-06.

\section{How to cite this article:}

Kamble Anand Shankar, L.N. Yogeesh, S.M. Prashant, P. Sheik Peer and Desai B.K. 2017. Integrated Farming System: Profitable Farming to Small Farmers. Int.J.Curr.Microbiol.App.Sci. 6(10): 2819-2824. doi: https://doi.org/10.20546/ijcmas.2017.610.330 